\title{
Effect on oestrus and ovulation of exposing creole goats to the male at three times of the year
}

\author{
P. Chemineau \\ I.N.R.A.-C.R.A.A.G., Station de Recherches Zootechniques, 97170 Petit-Bourg, Guadeloupe, \\ French West Indies
}

\begin{abstract}
Summary. The characteristics of the oestrous and ovarian cycles of local goats were studied over 2 years, on 96 females in March, 60 in July and 100 in November. After 3 weeks of separation between sexes, the females with inactive ovaries were identified and harnessed males were introduced. Detection of oestrus was undertaken daily and the date and rate of ovulation were checked at laparoscopies.

The proportion of females with non-cyclic ovaries before the mating period varied according to the season and whether the females were nulliparous or suckling. Among the females with inactive ovaries before the mating period, $97 \%$ ovulated 2.8 days after the introduction of males; $68 \%$ of these initial ovulations were accompanied by oestrus and $76 \%$ resulted in short luteal phases (5.3 days) followed by a second ovulation accompanied by oestrus $89 \%$ of the time. The proportions of initial ovulations with oestrus and of initial ovulations followed by a short luteal phase were in linear relationship with the proportion of females with non-cyclic ovaries before the mating period. For the females with cyclic ovaries before the mating period, the distribution of first oestrus during the 8 days after the introduction of males was significantly different from the expected uniform distribution. A possible luteolytic action of teasing was suspected. The fertility of females in all groups was high $(>79 \%)$. Litter size was not different for non-cyclic and for cyclic females.
\end{abstract}

\section{Introduction}

A study of the seasonal incidence of conceptions in 'creole' meat goats in Guadeloupe kept permanently with males on an Experimental Station has shown that these females have no marked reproductive season (Chemineau, 1981). However, in private flocks seasonal variation in available forage is accompanied by marked variation in breeding activity and conceptions (Cognié, Houix \& Logeay, 1971). In tropical areas it is particularly advantageous to synchronize kiddings to make the best use of available forage and to reduce as much as possible the need for supplementary food. Such synchronization must be simple and inexpensive and to this end, the technique of 'teasing' as used by Oldham, Martin \& Knight (1978) for sheep seems attractive. In tropical goats it is not known when 'teasing' is most effective or whether the characteristics of induced ovulation are such that fertility and prolificacy are equivalent to those of cyclic females.

The purpose of the present work was to answer these questions by studying the characteristics of oestrous and ovarian cycles, and the fertility and prolificacy of goats mated at three times of the year. 


\section{Materials and Methods}

Geography and climate. The research farm is in the dry part of Guadeloupe $\left(16^{\circ} 10^{\prime} \mathrm{N}, 61^{\circ} 40^{\prime} \mathrm{W}\right)$. Annual rainfall is $1236 \mathrm{~mm}$. Despite large variation between years it is possible to differentiate a rainy season (August-November $=755 \mathrm{~mm}$ ) and a dry season (December-July $=481 \mathrm{~mm}$ ). Maximum air temperature varies from $27^{\circ} \mathrm{C}$ (January) to $32^{\circ} \mathrm{C}$ (August) and minimum air temperature from 21 to $25^{\circ} \mathrm{C}$. Relative humidity is always above $55 \%$ and the daylength varies from 11 to 13 h.

Animals and mating periods. Animals were of the local 'creole' breed which is traditionally used for meat production (Cognie et al., 1971). The 157 females were used at one or more of 6 consecutive mating periods from July 1979 to March 1981 ; 256 individual exposures to the male were observed but it was not possible to have equal numbers of animals of each age and physiological state at each mating period (Table 1). At mating the procedure was to separate the females from any contact with the male for at least 3 weeks. Then $5-10 \%$ of harnessed vasectomized males (Radford, Watson $\&$ Wood, 1960) were introduced. This was called Day 0 . The occurrence of oestrus was checked daily, by identification of marked females, for at least 80 days after the beginning of mating. The oestrous females were mated with one of 5 previously selected, intact males. For the first 3 mating periods these males were used 8 days after the introduction of vasectomized males but for the last 3 periods mating began immediately females exhibited oestrus. All marked females were taken out of the flock in the morning $(07: 00-09: 00 \mathrm{~h})$ and after the first mating had been observed they were left with the intact male for $8-10 \mathrm{~h}$.

Animals were kept permanently on a Pangola grass (Digitaria decumbens) pasture and given concentrate at the rate of $0.3 \mathrm{~kg} /$ female/day. This concentrate contained $10600 \mathrm{~kJ}$ metabolizable energy $/ \mathrm{kg}$ and $135 \mathrm{~g}$ digestible crude protein $/ \mathrm{kg}$.

Measurements and recordings. Three blood samples were taken 14,7 and 1 or 0 days before males were introduced. By estimating the relative presence or absence of progesterone in plasma from these samples, females with inactive ovaries (i.e. non-cyclic females) could be differentiated from females with active ovaries (or cyclic females) before the mating periods (Terqui \& Thimonier, 1974). The last sample taken before mating in November 1980 was used to measure the exact levels of progesterone by the RIA method of Yenikoye et al. (1981). The sensitivity of the assay was 5 $\mathrm{pg} / \mathrm{ml}$ and the intra-assay coefficient of variation was $10.0 \%$.

One or two laparoscopies were performed 4-7 and 14-18 days after introduction of the males. The age of the corpora lutea was estimated from their size and colour (Oldham \& Lindsay, 1980). Kidding date and number of kids born were recorded. In August 1979 hurricane David killed 17 females, reducing to 27 the number of females providing fertility results in July 1979 .

Treatment of results. The length of an oestrous cycle was defined as the number of days between two consecutive periods of oestrus. Although some females were present at several mating periods, they were regarded as independent samples each time for statistical analysis. Standard $\chi^{2}, t$, randomization tests or linear coefficients of regression were used as appropriate (Snedecor \& Cochran, 1971).

\section{Results}

Response of non-cyclic females to teasing

The proportions of non-cyclic females before the mating period, pooling all physiological states (Table 1), differed significantly with time of year and were higher in July than in March and in March than in November (82, 49 and $21 \%$, respectively; $P<0.001$ ). If the mating period is disregarded, $94 \%$ of suckling females, $47 \%$ of non-suckling females and $32 \%$ of nulliparous females were non-cyclic $(P<0.05)$. Of the 117 non-cyclic females before introduction of males, $113(94 \%)$ ovulated after teasing; the mean \pm s.e.m. interval (days) was $2.9 \pm 0.3$ in July $1979 ; 2.0 \pm 0.3$ in 
Table 1. Number of females and proportion of non-cyclic females before exposure to the male relative to their physiological state and to time of mating*

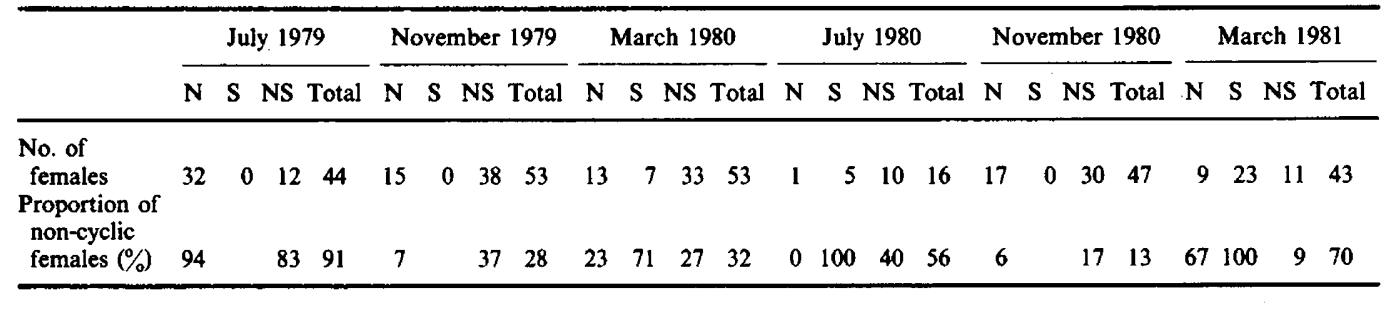

$\mathrm{N}=$ nulliparous; $\mathrm{S}=$ suckling; $\mathrm{NS}=$ not suckling.

* For 125 females the mean \pm s.e.m. kidding to mating interval was $100 \pm 4$ days.

November $1979,1 \cdot 7 \pm 0.3$ in March $1980,3 \cdot 3 \pm 1 \cdot 0$ in July $1980,1.8 \pm 0 \cdot 7$ in November 1980 and $3.8 \pm 0.4$ in March 1981 (overall mean, $2.8 \pm 0.2$ ). The interval seemed to be related to the proportion of non-cyclic females at the time of introduction of males because it averaged 3.3 days in the 3 periods when there were $>50 \%$ non-cyclic females, and only 1.8 days in the 3 periods when there were $<50 \%$ non-cyclic females $(P<0.05)$. For all 6 periods, $68 \%$ of first ovulations after teasing were accompanied by oestrus; this proportion $(y)$ varied with the mating period and was significantly correlated with the proportion $(x)$ of non-cyclic females in the flock $(y=-0.47 x+$ $97.2 ; r=-0.81, P<0.05$ ). However, $76 \%$ of these first ovulations were followed by corpora lutea with a short lifespan ( $<17$ days), almost all of which were $<9$ days (Text-fig. 1 ), the mean being $5 \cdot 3$ $\pm 0 \cdot 1$ days. The proportion of short lifespan corpora lutea at each period $(y)$ was significantly related to the proportion of non-cyclic females in the flock $(x)(y=0.98 x+13.3 ; r=0.95, P<$ $0.01)$ and with the proportion of nulliparous plus suckling females among the non-cyclic females $(x)$ $(y=0.80 x+21 \cdot 7 ; r=0.88, P<0.01)$. After this short cycle the goats ovulated a second time and this second ovulation was accompanied by an oestrus $89 \%$ of the time and was always followed by corpora lutea of normal lifespan.

For those females that had a short ovarian cycle after teasing and for which the two successive ovulations could be observed $(50 \%$ of the total), the ovulation rate was significantly $(P<0.05)$ lower at the first ovulation $(1.56)$ than at the second $(2.05)$ and the proportion of females with multiple ovulations increased from 42 to $72 \%$.

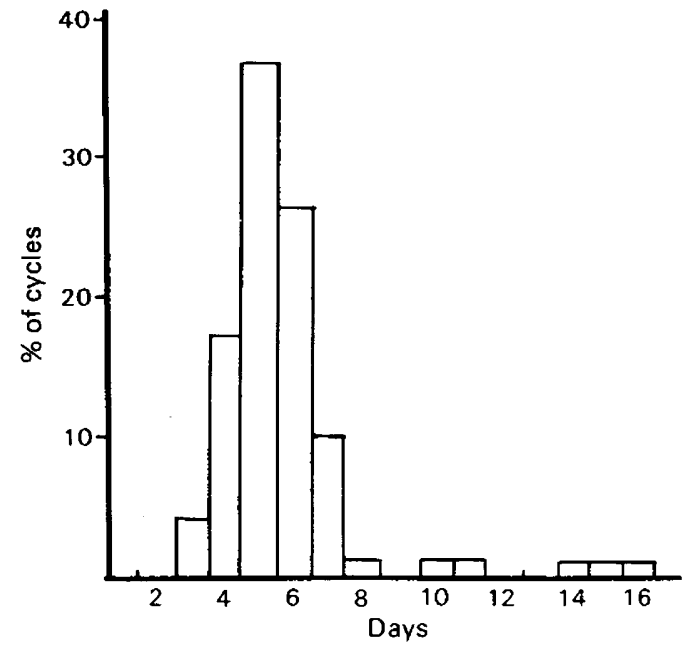

Text-fig. 1. Frequency of short cycles after teasing in females non-cyclic before the introduction of males. 


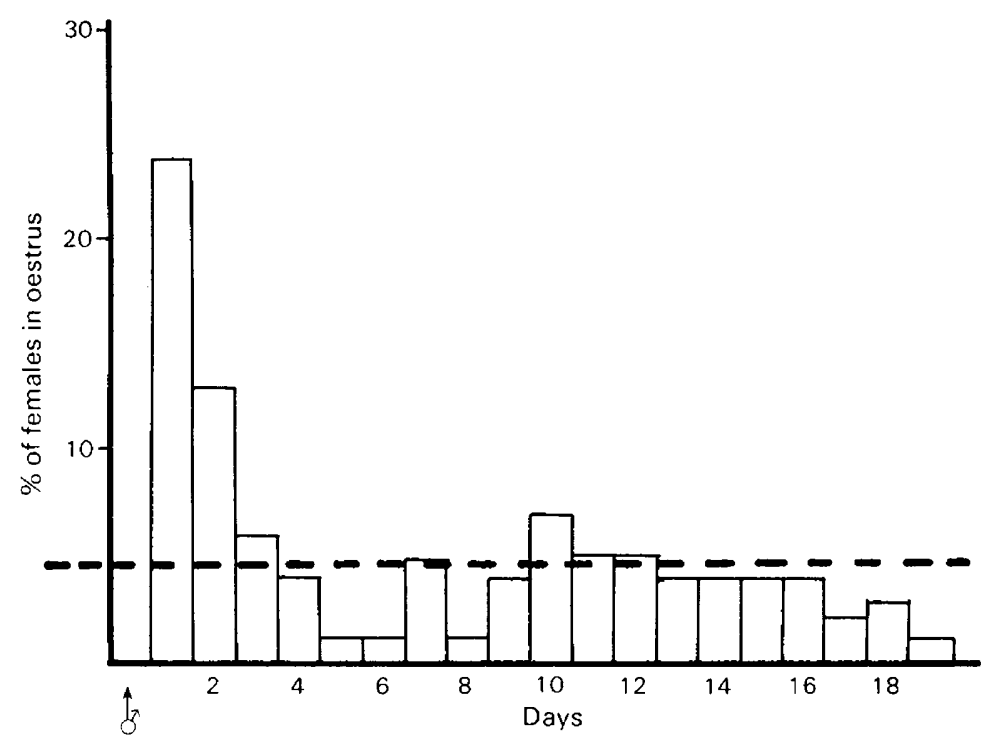

Text-fig. 2. Distribution of first oestrus after introduction of males (Day 0$)$ in females $(N=$ 136) that were cyclic before teasing. The broken line represents the uniform distribution. For Days $1-19, \chi^{2}=142.58, P<0.001$.

\section{Oestrous cycle characteristics of cyclic females before the mating period}

Out of the 137 cyclic females, 136 came into oestrus within 21 days after introduction of males, but the distribution of oestrus was significantly different from the expected uniform distribution (Text-fig. 2). The difference was observed during the first 8 days $\left(\chi^{2}=134.45 ; P<0.001\right)$. The highest frequency of oestrus was observed during the first 2 days and contrasted with the lowest incidence of oestrus during Days 5, 6 and 8. After Day 8 the distribution of oestrus was uniform (from Day 9 to $19: \chi^{2}=8.13 ; P>0.50$ ).

In November $1980,65 \%$ of the 37 females that were cyclic before the experimental period were in oestrus during the first 3 days of pairing instead of the $14 \%\left(\chi^{2}=18.37 ; P<0.001\right)$ expected if the patterns were regular. Among the females in the luteal phase (progesterone $>0.5 \mathrm{ng} / \mathrm{ml}$ ) on the day before introduction of males, those which came into oestrus before Day 6 had significantly $(P<0.05)$ less circulating progesterone $(2.95 \mathrm{ng} / \mathrm{ml})$ the day before introduction of males than did those which came into oestrus after this date $(5.06 \mathrm{ng} / \mathrm{ml})$ (Text-fig. 3).

Oestrous cycle patterns observed during the 6 mating periods showed a high proportion of short lifespan cycles relative to normal cycles (Table 2).

Table 2. Distribution of oestrous cycle lengths in goats after teasing

\begin{tabular}{lccc}
\hline & $\begin{array}{c}\text { Short } \\
(<17 \text { days })\end{array}$ & $\begin{array}{c}\text { Normal } \\
(17-26 \text { days })\end{array}$ & $\begin{array}{c}\text { Long } \\
(>26 \text { days })\end{array}$ \\
\hline No. of cycles & 39 & 39 & 10 \\
$(\%)$ & $(44)$ & $(44)$ & $(12)$ \\
Mean \pm s.e.m. & $6 \cdot 3$ & $20 \cdot 7$ & $36 \cdot 2$ \\
duration (days) & $\pm 0 \cdot 4$ & $\pm 0 \cdot 3$ & $\pm 2 \cdot 1$ \\
\hline
\end{tabular}




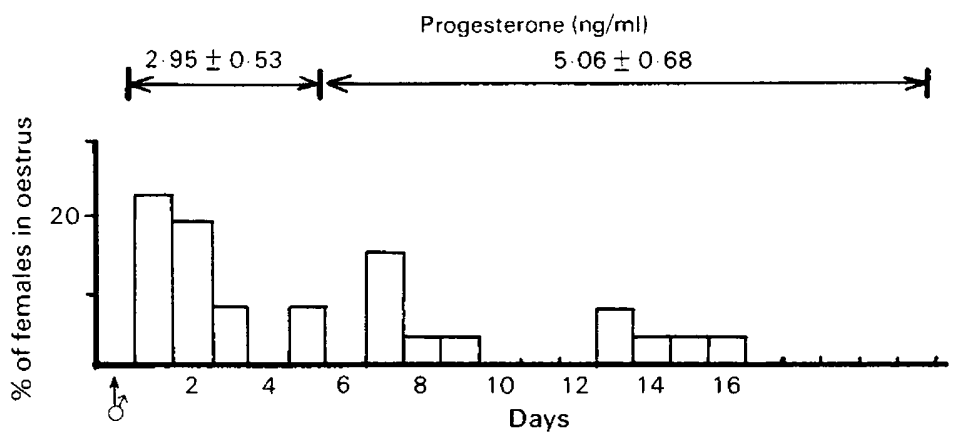

Text-fig. 3. Distribution of first oestrus after introduction of males (Day 0 ) in 28 cyclic females in which plasma progesterone concentrations (mean \pm s.e.m.) were also measured on Day -1 . All females were considered to be in the luteal phase of the cycle on Day $-1(>0.5 \mathrm{ng}$ progesterone/ml).

\section{Fertility and prolificacy}

Fertility (Table 3) did not differ significantly for any of the categories of female or after mating in March, July or November. Prolificacy (Table 3) was lower for nulliparous than for primi- and multiparous females and in July than in March and November, but did not differ between females that were cyclic or non-cyclic before the introduction of males.

Table 3. Fertility and prolificacy of females relative to their ovarian activity before introduction of males, their parity and the time of mating

\begin{tabular}{lccc}
\hline & No. of litters & Fertility $\%$ & Prolificacy \\
\hline $\begin{array}{l}\text { Goats cyclic } \\
\text { before introduction } \\
\text { of male }\end{array}$ & 109 & 81 & 1.97 \\
$\begin{array}{l}\text { Goats non-cyclic } \\
\text { before introduction } \\
\text { of male }\end{array}$ & 88 & 87 & 1.85 \\
\hline $\begin{array}{l}\text { Nulliparous } \\
\text { Primiparous \& }\end{array}$ & 59 & 80 & $1.61^{*}$ \\
\hline multiparous & 138 & 85 & $2.05^{*}$ \\
\hline $\begin{array}{l}\text { Mating in March } \\
\text { Mating in July } \\
\text { Mating in November }\end{array}$ & 86 & 90 & 1.92 \\
\hline Total & 79 & 82 & $1.64 \dagger$ \\
\hline
\end{tabular}

$* P<0.001$.

† Significantly different from values for March and November, $P<0.01$.

\section{Discussion}

The proportion of non-cyclic females before the mating period varied according to season (13-91\%) and physiological state of the females (32-94\%) and reflects interactions between seasonal 'anoestrus' (Y. Cognié, personal communication; Chemineau, 1981) and prepubertal or post-partum ovarian inactivity periods (Mauléon, 1980). 
For the 'creole' meat goat with inactive ovaries before the mating period, introduction of males induces ovulation in almost all females, as shown for other breeds of goat with a single introduction just before the breeding season (Shelton \& Morrow, 1965; Gonzales-Stagnaro, 1976; Ott, Nelson \& Hixon, 1980). This first ovulation is accompanied by oestrus in most cases as has been shown for the dairy (Ott et al., 1980) and Angora (Shelton \& Morrow, 1965) nanny goat. This response differs from that reported for the 'creole' goat of Venezuela (Gonzales-Stagnaro, 1976) and for the ewe (Prud'hon \& Denoy, 1969; Underwood, Shier \& Davenport, 1944) in which only a few animals display oestrus at the first ovulation after teasing. The first ovulation occurs within 5 days after the introduction of the male, as in the ewe (Knight, Peterson \& Payne, 1978) and in the dairy goat (Ott et al., 1980). It is likely that the physiological mechanisms set in action are identical to those described in the ewe for which introduction of the male provokes an immediate increase in the frequency of LH pulses (Poindron et al., 1980; Martin, Oldham \& Lindsay, 1980) leading to a preovulatory LH peak (Oldham et al., 1978). The variation in the interval between teasing and ovulation and the strong relationship between oestrus at the first ovulation after teasing and percentage of non-cyclic females in the flock suggest that these physiological mechanisms could be modified by season or by the 'depth of anoestrus' (Lindsay \& Signoret, 1980) of females at introduction of males.

The regularity (whatever the season or the physiological state of females may be) in the duration of the short ovarian cycle after teasing suggests that luteotrophic and luteolytic mechanisms controlling short cycles are well defined and follow a definite pattern. The strong relationship between the proportions of short ovarian cycles and of non-cyclic females in the flock indicates that the latter 'index', based on all the females exposed to the male, could reflect the degree of sexual inactivity of the non-cyclic females before teasing, as suggested by Lindsay \& Signoret (1980) for non-cyclic ewes. The strong relationship between the proportion of nulliparous plus suckling females among non-cyclic females supports this hypothesis. It is more difficult to induce ovulation with exogenous hormones in suckling than in non-lactating females (Thimonier, Mauléon, Cognié \& Ortavant, 1968). In other goat breeds (Ott et al., 1980) or other species such as the ewe (Oldham \& Martin, 1978) a short luteal phase following the first ovulation after teasing also occurs in $>50 \%$ of animals. The oestrus that accompanies the second ovulation after teasing and is followed by a normal luteal phase suggests that the hypothalamo-pituitary system may require priming by the small amount of progesterone secreted after the first ovulation (Robinson, 1959; Oldham, Cognié, Poindron \& Gayerie, 1980). In contrast to results for the ewe (C. M. Oldham, unpublished), the ovulation rate in these goats was significantly greater at the second ovulation than at the first, and the number of ovulations was similar to that in cyclic females.

The male effect has normally been associated only with non-cyclic females. Our results suggest that the introduction of the male may also influence the cyclic pattern of spontaneously ovulating animals. Some of the high oestrous activity on the first day of introduction of the male may be explained by the fact that some females in oestrus the previous day may have been marked by males. This could certainly not be the case on Day 2. Therefore, it appears that the presence of males may have induced rapid luteolysis and early ovulation in the females which would normally have ovulated several days later. This hypothesis is consistent with the small number of females in oestrus on Days 5-8 because they probably ovulated on Days 1-4. In November 1980, when accurate measurements of plasma progesterone concentrations were made the day before introduction of males, goats becoming oestrous within 5 days after exposure to the male had much lower progesterone values than did those becoming oestrous later. This suggests that this level of progesterone may not be sufficient to block the secretion of LH after introduction of the male (see Poindron et al., 1980), and the subsequent secretion of oestrogens may thus induce rapid luteolysis and oestrus. This shortening of the length of the oestrous cycle has already been observed in rodents (review of Signoret, 1980). However, the present results need to be confirmed because the records before introduction of males are not sufficiently precise to permit definition of the exact stage of the oestrous cycle for each female and I cannot be sure that for some unknown reason the cycles were not previously synchronized. 
The high proportion of short cycles, also observed by Y. Cognié (personal communication) for non-breeding females, indicates that ovarian activity of 'creole' nanny goats is irregular, but these observations were made mostly on females which did not conceive at the first oestrus and our sample may have been less fertile than normal.

However, use of the male effect will result in $80 \%$ fertility in 'creole' goats regardiess of season or physiological state. This contrasts markedly with the variable sporadic activity of the animals if the male effect is not used. Prolificacy, although always above $1.61 \mathrm{kids} / \mathrm{goat}$, seems to be more sensitive. However, the conditions under which our observations were made do not allow us to distinguish which of several factors, such as cyclicity of females, physiological state or season of mating, may be important in improving prolificacy.

I thank Dr David Lindsay (University of Western Australia), Dr Yves Cognié (I.N.R.A., Nouzilly) and Dr J. Thimonier for advice and help in the preparation of this manuscript; and Miss Nati Poulin (I.N.R.A., Nouzilly) and Mr H. Varo for technical assistance.

\section{References}

Chemineau, P. (1981) Eficiencia reproductiva de cabras para carne criollas en asociacion permanente con machos. Proc. 8th Reun. Asoc. lat. am. Prod. Anim., Santo Domingo, Abstr. F 50.

Cognié, Y., Houix, Y. \& Logeay, B. (1971) Données sur la croissance et la reproduction de la chèvre créole en Guadeloupe. Proc. 2nd Int. Conf. Elevage caprin, Tours, pp. 345-350.

Gonzales-Stagnaro, C. (1976) El "Efecto macho" sobre la estacionalidad sexual en cabras del medio tropical. Mems Asoc. lat. am. Prod. Anim. 11, 69, Abstr.

Knight, T.W., Peterson, A.J. \& Payne, E. (1978) The ovarian and hormonal response of the ewe to stimulation by the ram early in the breeding season. Theriogenology 10, 343-348.

Lindsay, D.R. \& Signoret, J.P. (1980) Influence of behaviour on reproduction. Proc. 9th Int. Congr. Anim. Reprod. \& A.I., Madrid 1, 83-92.

Martin, G.B., Oldham, C.M. \& Lindsay, D.R. (1980) Increased plasma LH levels in seasonally anovular Merino ewes following the introduction of rams. Anim. Reprod. Sci. 3, 125-132.

Mauléon, P. (1980) Variations circannuelles de la fertilité chez les mammifères domestiques. In Rythmes et Reproduction, pp. 14-32. Eds R. Ortavant \& A. Reinberg. Masson \& Cie, Paris.

Oldham, C.M. \& Lindsay, D.R. (1980) Laparoscopy in the ewe : a photographic record of the ovarian activity of ewes experiencing normal or abnormal oestrous cycles. Anim. Reprod. Sci. 3, 119-124.

Oldham, C.M. \& Martin, G.B. (1978) Stimulation of seasonally anovular Merino ewes by rams. II. Premature regression of ram induced corpora lutea. Anim. $R e$ prod. Sci. 1, 291-295.

Oldham, C.M., Martin, G.B. \& Knight, T.W. (1978) Stimulation of seasonally anovular Merino ewes by rams. I. Time from introduction of the rams to the preovulatory LH surge and ovulation. Anim. Reprod. Sci. 1, 283-290.

Oldham, C.M., Cognié, Y., Poindron, P. \& Gayerie, F. (1980) The influence of progesterone or FGA priming on the ovarian function of seasonally anovular ewes induced to ovulate by their reintroduction to rams, teasing. Proc. 9th Int. Congr. Anim. Reprod. \& A.I., Madrid 3, 50.

Ott, R.S., Nelson, D.R. \& Hixon, J.E. (1980) Effect of presence of the male on initiation of estrous cycle activity of goats. Theriogenology 13, 183-190.

Poindron, P., Cognié, Y., Gayerie, F., Orgeur, P., Oldham, C.M. \& Ravault, J.P. (1980) Changes in gonadotrophins and prolactin levels in isolated (seasonally or lactationally) anovular ewes associated with ovulation caused by the introduction of rams. Physiol. Behav. 25, 227-236.

Prud'hon, M. \& Denoy, I. (1969) Effets de l'introduction de béliers vasectomisés dans un troupeau Mérinos d'Arles, quinze jours avant le début de la lutte de printemps, sur l-apparition des oestrus, la fréquence des erreurs de détection des ruts et la fertilité des brebis. Annls. Zootech. 18, 95-106.

Radford, M.M., Watson, R.H. \& Wood, G.E. (1960) A crayon and associated hamess for the detection of mating under field conditions. Aust. vet. J. 36, 56-66.

Robinson, T.J. (1959) The oestrous cycle of the ewe and doe. In Reproduction in Domestic Animals, lst edn, Vol. I, pp. 291-333. Eds H. H. Cole \& P. T. Cupps. Academic Press, New York.

Shelton, M. \& Morrow, T. (1965) A study of the mechanism of male stimulation in Angora goats. Rep. $T x$ Agr. Exp. Stn pp. 20-21.

Signoret, J.P. (1980) Effet de la présence du mâle sur les mécanismes de reproduction chez la femelle des mammifères. Reprod. Nutr. Dévelop. 20, 1457-1468.

Snedecor, G.W. \& Cochran, W.G. (1971) Statistical Methods, 6th edn. Iowa State University Press, Ames.

Terqui, M. \& Thimonier, J. (1974) Nouvelle méthode radioimmunologique rapide pour l'estimation du niveau de progestérone plasmatique. Application pour le diagnostic précoce de la gestation chez la brebis et chez la chèvre. C. r. hebd. Séanc. Acad. Sci., Paris D 279, $1109-1112$.

Thimonier, J., Mauléon, P., Cognié, Y. \& Ortavant, R. (1968) Déclenchement de l'oestrus et obtention de la gestation pendant l'anoestrus post-partum chez la brebis à l'aide d'éponges vaginales imprégnées d'acétate dea fluorogestone. Afints ' Zootech. 17, 257/273. 01:55:46PM 
Underwood, E.J., Shier, F.L. \& Davenport, N. (1944)

Studies in sheep husbandry in Western Australia. V. The breeding season of Merino crossbred and British Breed ewes in the agricultural districts. J. Agric. West. Aust. 11, 2, 135-143.
Yenikoye, A., Mariana, J.C., Ley, J.P., Jolivet, E., Terqui, M. \& Lemon-Resplandy, M. (1981) Modèle mathématique de l'evolution de progestérone chez la vache: application et mise en évidence de différences entre races. Reprod. Nutr. Dévelop. 21, 561-575.

Received 5 April 1982 